\title{
MOTIVÁCIÓ VIZSGÁLATA HERZBERG KÉTTÉNYEZŐS MODELLJE ÉS AZ ÖNDETERMINÁCIÓS ELMÉLET ALAPJÁN
}

INVESTIGATION OF MOTIVATION BASED ON HERZBERG'S TWO-FACTOR MODEL AND SELF-DETERMINATION THEORY

\section{Dajnoki Krisztina $^{1}$, Ujhelyi Mária ${ }^{2}$, Filep Roland ${ }^{3}$}

\author{
${ }^{1,2}$ Egyetemi docens, ${ }^{3} \mathrm{PhD}$ hallgató \\ ${ }^{1}$ Debreceni Egyetem, Gazdaságtudományi Kar, Vezetés- és Szervezéstudományi Intézet, \\ Emberi Erőforrás Menedzsment Tanszék, \\ ${ }^{2}$ Debreceni Egyetem, Gazdaságtudományi Kar, Vezetés- és Szervezéstudományi Intézet, \\ Vezetéstudományi Tanszék, \\ ${ }^{3}$ Debreceni Egyetem, Ihrig Károly Gazdálkodás- és Szervezéstudományok Doktori Iskola, \\ E-mail: dajnoki.krisztina@econ.unideb.hu1,ujhelyi.maria@econ.unideb.hu², \\ filep.roland@econ.unideb.hu ${ }^{3}$
}

\section{Összefoglalás}

Napjainkban az emberi erőforrás felértékelődése világméretű jelenség, a hagyományos HR funkciókon belül a motiváció és ösztönzés kérdésköre közkedvelt és kihívást jelentő területet jelent. Tanulmányunkban egy szolgáltató szervezet dolgozóinak motiváltságát meghatározó tényezők vizsgálatát tűztük ki célul. Ennek érdekében Herzberg kéttényezős modelljét és az Öndeterminációs elmélet tényezöit elemeztük. Arra a kérdésre kerestünk választ, hogy valóban olyan fontos kulcstényezőként jelenik-e meg a munkahelyhez való kötődés és a jó munkahelyi légkör, mint ahogyan azt az aktuális szakirodalmi elemzések bemutatják. Megkérdeztük a munkavállalókat arról, hogy a Herzberg-modellben szereplő jellemzők közül egy ideális munkahely esetében mit tartanak fontosnak, valamint a jelenlegi munkahely milyen lehetőséget teremt az Öndeterminációs elméletben szereplő három pszichológiai szükséglet gyakorlására. A regresszió elemzés eredményei alapján megállapítottuk, hogy a „kreatív, önálló munkavégzésre való ösztönzés” és az „egyéni szakmai fejlődés biztosítása” pozitív kapcsolatban áll a motiváltsággal, az ,alapbér fontossága” ezzel fordított irányú összefüggést mutat. Ez utóbbit az „elvégzett munka, kapott bér egyensúlya” változóval korrelációszámítással vizsgálva megállapítható, hogy a változók között fordított irányú a kapcsolat, azaz minél magasabb a bérigény, annál kisebb az elvégzett munkához viszonyított észlelt egyensúly. A válaszadók megítélése szerint többet tesznek a szervezetért, mint amennyi ellenszolgáltatást kapnak érte. Az eredmények alapján a vizsgált szervezetben a dolgozók motiváltságának fenntartása, fokozása érdekében a vezetőknek oda kell figyelniük arra, hogy a beosztottaknak lehetőséget biztosítsanak a folyamatos szakmai fejlődés mellett az önálló, kreatív munkavégzésre is. A munkabér növelése Herzberg szerint nem motivátor, hanem higiénés tényező, így nincs hatással az elégedettségre, ezáltal a motiváció növelésére, viszont az elégedetlenséget csökkentheti, ezért a vezetőknek érdemes erre is gondot fordítaniuk. Hasonló a helyzet a jó munkahelyi kapcsolatokkal, amely a regressziós modellbe ugyan nem került be, de mindkét modellben a legmagasabb átlagértékeket kapta.

\begin{abstract}
Nowadays, the appreciation of human resources is a global phenomenon, the issue of motivation and incentive within traditional HR functions is a popular and challenging area. In our study, we aimed to examine the factors that determine the motivation of the employees of a service organization. To this end, we analysed Herzberg's two-factor model and the factors of the Self-Determination Theory. We sought to answer the question of whether workplace
\end{abstract}


attachment and a good workplace atmosphere really appear to be as important key factors as the current literature analyses show. We asked workers what of the characteristics in the Herzberg model they consider important for an ideal workplace and what the current workplace provides an opportunity to address the three psychological needs in Self-Determination Theory. Based on the results of the regression analysis, we found that "encouraging creative, independent work" and "ensuring individual professional development" are positively related to motivation, with the "importance of basic wages" showing an inverse relationship with this. Examining the latter with the variable "work done, balance of wages received" by correlation calculation, it can be stated that the relationship between the variables is reversed, ie the higher the wage demand, the smaller the perceived balance in relation to the work performed. Respondents believe they do more for the organization than they receive from it. Based on the results, in order to maintain and increase the motivation of the employees in the examined organization, the managers must pay attention to providing the subordinates with the opportunity not only for continuous professional development but also for independent, creative work. Increasing wages, according to Herzberg, is not a motivator, but a hygienic factor, so it has no effect on satisfaction, thereby increasing motivation, but it can reduce dissatisfaction, so managers should take care of this, as well. The situation is similar in case of good workplace relationships, which, although was not included in the regression model, but received the highest mean values in both models.

Kulcsszavak: emberi erőforrás, motiváció, szervezeti magatartás, ösztönzés, szolgáltató szervezet

JEL besorolás: 015

LCC: HD58.7-58.95

\section{Bevezetés}

A motiváció kérdésköre a kutatókat és a gyakorlati szakembereket egyaránt foglalkoztatja. Sipos (2016) szerint a dolgozók teljesítményének befolyásolóit keresve a munkahelyi motiváció kérdésköre jelenti az egyik legfontosabb tényezőt. Megfelelö motiválás nélkül nem várható el kimagasló teljesítmény, értékteremtés. Csehné és Varga (2017) is ezt támasztja alá, a munkahelyhez való kötődés, az elégedettség, és a jó munkahelyi légkör mellett a motivált hozzáállást nevezik meg annak a tényezőnek, amely lényeges és hosszú távú hatást gyakorol a teljesítményre. Dhurup et al. (2016) éppen az ezek közötti kapcsolatot vizsgálta, szignifikáns összefüggést talált a munkatársakkal való kapcsolat, a csapatmunka és a dolgozói elégedettség között. Szerinte a csapatmunka megfelelő menedzselése elengedhetetlenül fontos az olyan ágazatokban, ahol csak ezen a módon tudnak eredményesen dolgozni. Erro-Garcés és Ferreira (2019) szerint ma már a munkahelyi környezeti feltételek olyannyira fontos szerepet játszanak a munkával való elégedettségben, mint a szerződéses feltételek, vagy a béremelés.

A tanulmány a motiváció széles spektrumán belül, a motiváció tartalom- és folyamatelméleteinek rövid áttekintését követően azt vizsgálja, hogy a Herzberg kéttényezős modelljében szereplő jellemzők közül mit tartanak igazán fontosnak a munkavállalók. Elemezzük továbbá azt is, hogy a jelenlegi munkahely milyen lehetőséget teremt a szakmai fejlődésre, valamint arra, hogy a munkavégzés során a szoros ellenőrzés helyett önmaguk felett gyakoroljanak kontrollt, és ezek mellett jó munkavállalói kapcsolatok alakuljanak ki, amelyek az Öndeterminációs elmélet szerint (Deci és Ryan, 2017) szintén fontosak a megfelelő motiváltság kialakulásában. 
A továbbiakban a motivációval kapcsolatos elméleteket tekintjük át, amelyen belül részletesebben foglalkozunk Herzberg kéttényezős modelljével és az Öndeterminációs elmélettel.

\section{Motiváció}

A motiváció hajlandóságot jelent a szervezeti célok megvalósítására, amellyel egyben egyéni szükségleteket elégítünk ki (Bakacsi, 2004). A motivációnak komoly jelentősége van, megfelelö motiváltság nélkül a szervezetek nem számíthatnak kimagasló teljesítményre a munkatársaik részéről (Farkas et al., 2013). A teljesítmény révén a vezetők erősen érdekeltek a megfelelő motiváltság kialakításában, hiszen komoly nyomás alatt vannak, hogy a tulajdonosok által elvárt teljesítményszintet elérjék (Fenyves et al., 2018).

A fentiekből adódóan a motiváció témaköre népszerü területet jelent a szakirodalomban. Bakacsi (2004) alapján a motivációs elméletek két nagy csoportba sorolhatók, amelyet a tartalom- és folyamatelméletek jelentenek. Sunil (2004) hangsúlyozza, hogy a szervezetekben a kulcsemberek megtartása érdekében mindenképpen szükséges azonosítani és elemezni a munkavállalók megtartását megalapozó motivációs elméleteket.

A tartalomelméletek azt tárják fel, hogy mire van szüksége a munkavállalóknak és ehhez a vezetők milyen eszközöket használhatnak, Kreitner és Kinicki (2009) szerint azért is szükséges ismerni ezeket az elméleteket, mert az emberek igényei időről időre változnak. Bakacsi (2004) alapján az egyazon csoportba tartozó tartalomelméletek is más-más nézőpontból közelítik meg a motivációt, egyik sem tekinthető alapnak. Maslow szükséglethierarchia-elmélete, Herzberg kéttényezős modellje, Alderfer létezés-kapcsolat-fejlődés elmélete, McClelland kapcsolatteljesítmény-hatalom elmélete és Hunt cél-motiváció elmélete kapcsolódnak ide. Egyik lényeges különbség a modellek között, hogy Maslow merev szükséget-piramisa nincs tekintettel az egyéni különbségekre, Alderfer és Hunt rugalmas szerkezetet ajánl, Herzberg pedig különválasztja az elégedettséget és az elégedetlenséget befolyásoló jellemzőket. A különbségek ellenére mindegyik közelebb visz a magatartás megértéséhez, ezért hasznosak lehetnek a gyakorló vezetők számára is.

Kreitner és Kinicki (2009) alapján a folyamatelméletek azon a felvetésen alapulnak, hogy a motiváció a munkavállalók észlelésének és meggyőződésének függvényében változik. Megmutatják, hogy az egyéni szükségletekböl, törekvésekböl megszerzett ismereteket a vezetők hogyan tudják hasznosítani az egyének magatartásának megfelelö irányba terelése érdekében. Az egyéni célokkal, erőfeszítésekkel, teljesítménnyel, következményekkel kapcsolatban keresnek összefüggéseket. Bakacsi (2004) összefoglalása alapján Skinner megerösítés elmélete hangsúlyozza, hogy a következmények befolyásolják azt, hogy az egyén ismétli-e a korábbi magatartását. Hunt célkitüzés elmélete szerint a kihívó teljesítmény elvárások inspirálnak erőfeszítésekre. Vroom elvárás elmélete alapján az egyének a teljesítményt az erőfeszítésekkel és a következményekkel is összevetve hoznak döntést az erőfeszítésekről. Adams méltányosság elmélete azt mondja ki, hogy az egyén az erőfeszítést és az eredményt veti össze egymással. (Juhász, 2004) A folyamatelméletek azért is hasznosak, mert javíthatják a tartalomelméletek alkalmazásának hatásfokát.

A továbbiakban kizárólag a tartalomelméletekkel foglalkozunk részletesebben, ezek közül pedig kifejezetten Herzberg kéttényezős modelljére helyezzük a hangsúlyt. A modell nagy múltra tekint vissza és máig használják motivációs vizsgálatoknál. Napjaink kutatásainál többek között Dhamija et al. (2019) a versenyszférában dolgozók, Hur (2018) pedig az állami szektor alkalmazottainak munkahelyi elégedettségét is elemezte a segítségével. Herzberg 
megkülönböztette a motivátorokat és a higiéniés tényezőket. Az elöbbiek a munkával való megelégedettséget, az utóbbiak pedig az alacsonyabb rendü szükségleteket foglalják magukba. Sipos (2016) véleménye alapján az ugyancsak tartalomelméletekhez tartozó Maslow szükséglethierarchiájához képest jelentős gondolati fejlesztés jelenik meg Herzberg modelljénél, mivel a két tényezőhöz kapcsolódóan megállapította, hogy a motivátorok az elégedettség kialakításához járulnak hozzá, viszont hiányuk nem jelent feltétlenül elégedetlenséget, a higiénés tényezők pedig nem okoznak munkával kapcsolatos elégedettséget, csupán az elégedetlenséget szüntetik meg. A fizetés az egyik legérdekesebb higiénés tényező olyan szempontból, hogy gyakran használják motivációs kísérletekben annak ellenére, hogy a modell szerint nem motivátor. A fizetés már a munkaeröpiacra történő belépést megelőzően, a hallgatók körében is kulcskérdést jelent. Kiss és szerzőtársainak (2017) kutatása alapján a fizetéssel kapcsolatos elvárások a leendő diplomás munkavállalók esetében több, mint 10\%-al magasabbak az átlagkeresetnél. A méltányosság elmélet szerint (Bakacsi, 2004) a fizetés akkor jelent problémát, ha a dolgozók azt észlelik, hogy az lényegesen alacsonyabb, mint a saját, vagy más szervezetben hasonló feladatokat ellátók fizetése. Herzberg (1987) modellje alapján ennek korrekciójával az elégedetlenség csökken, de a motiváció nem növekszik. A bér csak bizonyos szintig csökkenti az elégedetlenséget, ezután nem lehet tovább csökkenteni és vélhetően más higiénés tényezőben keresendő a dolgozó elégedetlenségének forrása. Az 1. táblázatban mutatjuk be Herzberg kéttényezős modelljében szereplő motivátorokat és higiénés tényezőket.

\section{1. táblázat: Herzberg kéttényezős modellje}

\begin{tabular}{|l|l|}
\hline Motivátorok & Higiénés tényezök \\
\hline elörelépési lehetőség & vezetés minősége (ideális felettes) \\
\hline kihívást jelentő feladatok & munkahelyi légkör \\
\hline maga a munka (szakmai érdeklődés) & fizetés (alapbér, béren kívüli juttatás) \\
\hline elismerés (és dicséret) & munkakörülmények (rugalmas munkaidö) \\
\hline megbecsülés és tisztelet & munkahely biztonsága \\
\hline felelösség (önálló munkavégzés) & \\
\hline
\end{tabular}

Forrás: Saját szerkesztés Herzberg (1987), Bakacsi (2004) és Sipos (2016) alapján

Bakacsi (2015) alapján napjaink menedzsmentirodalma az önmegvalósításhoz kapcsolódó motivációt taglalja. Ha el tudja érni a vezető, hogy a szervezet céljai a részét képezzék az egyén önmegvalósításának, akkor ez olyan belső késztetést jelent, amely által az önmegvalósító munkavállaló a legnagyobb áldozatokra is kész a saját vágyainak elérése érdekében. Az önmegvalósító egyén jellemző tulajdonságai közé tartozik, hogy képes önálló lenni, jól türi a bizonytalanságot, kreatív; gyakorlatias, inkább a problémákra, mint önmagára összpontosít; elfogadja magát és másokat is olyannak amilyenek, törődik a társadalom jólétével. Ezeket a jellemzőket a következő bekezdésben részletezett öndeterminációs elméletnél is fellelhetjük.

\section{Öndeterminációs elmélet}

Az Öndeterminációs elmélet (Deci - Ryan, 2012, 2017) alapján az embernek három veleszületett pszichológiai szükséglete van: az autonómia (önmagát irányítsa) a kompetencia (szakmai fejlődés) és a kötődés (kapcsolatban legyen másokkal). Akkor lehet egy munkavállaló motivált és produktív, ha ezek teljesülnek.

Az autonómia az egyéneknek azt az igényét írja le, hogy ne folyamatos, szoros kontroll és nyomás alatt dolgozhassanak, hanem önszabályozók legyenek, ez az önállóság nagymértékben segíti a kreativitás kibontakozását. Napjaink leadership elméletei is kiemelik ennek a fontosságát (Dvir et al., 2002). Kanat-Maymon et al. (2020) kapcsolatot talált a vezetési stílus 
és az autonómia között, eredményei alapján a középvezetök részére biztosított nagyobb autonómia elősegíti a transzformációs vezetési stílus gyakoribb alkalmazását, amely Avolio és Bass (1991) szerint a leghatékonyabb stílusnak tekinthető. Nalipay et al. (2020) több, mint 92 ezres hallgatói mintán végzett elemzése alapján az autonómia biztosítása a keleti és a nyugati kultúrák számára egyaránt fontos volt hallgatói eredményesség szempontjából is. A kompetencia arra utal, hogy a munkavállaló lehetőséget kap az egyéni képességek fejlesztésére, szakmai fejlődésre, a tehetségének gyakorlására. A kompetenciát nem csupán a munkavállalók tartják fontosnak, Varga és szerzőtársai (2017) szerint az emberi erőforrás menedzsment egyik kulcsfontosságú fogalmává nőtte ki magát. A fejlődés iránti igény, a tudásra irányuló belső motiváció érthető módon már egyetemi hallgatók körében végzett empirikus vizsgálatnál is megjelenik az első három tényező egyikeként (Kiss, 2015). Már a tanulmányok során nyújtott többletteljesítmény is kifizetődő lehet, ugyanis Kiss és Barizsné alapján (2018) a munkaadók magasabb termelékenységgel azonosítják ezeket a hallgatókat, és a kiválasztási folyamataik során kiszürik a jobb eredményt felmutatókat. A három közül az utolsó szükséglet a kötődés, amely a másokkal, munkatársakkal való kapcsolat iránti szükségletet hangsúlyozza. Az egyénnek szüksége van arra, hogy érezze fontos másoknak és ő maga is jóindulatú hozzáállást kövessen más egyénekkel szemben. Ez utóbbit Gergely és Pierog (2016) civil szervezetek körében végzett kutatása is megerösíti. Megállapították, hogy a célkitüzés mellett a valahova tartozás érzése a leginkább használható motivációs eszköz, ami az emberek egyik alapvető szükséglete.

A következökben a primer kutatásunkat mutatjuk be, amelynek alapját Herzberg (1987) kéttényezős modellje, valamint Deci és Ryan (2012) Öndeterminációs elmélete képezi.

\section{Anyag és módszertan}

Egy országos hálózattal rendelkező szolgáltató szervezet dolgozóit kérdeztük meg a motiváció témakörével kapcsolatban $(\mathrm{N}=100)$. Az anonimitás biztosítása érdekében a kézirat további részében a „szolgáltató szervezet” elnevezést használjuk. A 100-as elemszámú minta a szervezet helyi, regionális egységeiben dolgozóknak közel egynegyedét fedi le. A minta nemek és korcsoport szerinti összetételét a 2. táblázat tartalmazza.

2. táblázat: Minta nemek és korosztály szerinti megoszlása (fö)

\begin{tabular}{|l|l|l|l|l|l|}
\hline \multirow{2}{*}{ Nem } & \multicolumn{5}{c|}{ Korosztály } \\
\cline { 2 - 6 } & \multicolumn{1}{|c|}{$18-24$} & \multicolumn{1}{c|}{$25-39-54$} & \multicolumn{1}{c|}{ 54 felett } & \multicolumn{1}{c|}{ Összes } \\
\hline Nő & 4 & 33 & 36 & 6 & 79 \\
\hline Férfi & 0 & 8 & 11 & 2 & 21 \\
\hline Összesen & 4 & 41 & 47 & 8 & 100 \\
\hline
\end{tabular}

Forrás: Saját vizsgálat

A saját szerkesztésü kérdőív a háttérváltozók mellett motivációs kérdéseket tartalmaz. Ezeknek az egyik része általános kérdéseket fogalmaz meg a munkahellyel kapcsolatos különböző tényezők fontosságáról, amelyek Herzberg (1987) kéttényezős modelljén alapulnak. Egyes kérdéseit Farkas és szerzőtársai (2013) is alkalmazták már motivációval kapcsolatos empirikus kutatásnál. A másik része pedig olyan konkrét kérdéseket tartalmaz a jelenlegi munkahelyen tapasztaltakról, amelyek az Öndeterminációs elmélet szerint (Deci - Ryan, 2012) hatással lehetnek a motivációra.

Az első kérdésblokk arra keresi a választ, hogy mennyire tartja fontosnak egy munkahellyel kapcsolatban a következöket: szakmai érdeklődés, magas alapbér, béren kívüli juttatások, 
kihívást jelentő feladatok, munkahelyi légkör és közösség, rugalmas munkaidő, előrelépési lehetőség, ideális felettes, megbecsülés és tisztelet, önálló munkavégzés, elismerés és dicséret, biztonság. A további kérdések arra vonatkoznak, hogy ösztönzi-e a felettese kreatív és önálló munkavégzésre, mennyire látja biztosítottnak a szakmai fejlődését, mennyire elégedett a kollégáival tartott kapcsolattal. A fenti változóknak a dolgozó motiváltságára való hatását vizsgáljuk, kérdésünk, hogy „Motiváltnak érzi-e magát jelenlegi munkahelyén”?

Többszörös lineáris regresszió használatával, stepwise eljárással a motiváltság (függő változó) és a kérdöívünkben a szakirodalom (Herzberg, 1987; Deci - Ryan, 2017) alapján összeállított kérdésekre (független változók) adott válaszok közötti kapcsolatot vizsgáltuk. A függő és a független változók esetében is Farkas és szerzőtársainak (2013) motivációval kapcsolatos empirikus kutatásához hasonlóan négy fokozatú Likert-típusú értékelöskálán történő mérést végeztünk a középső (semleges) érték kihagyásával annak érdekében, hogy egyértelmü választásra, véleményformálásra vegyük rá a megkérdezetteket.

A számításaink során a végső regressziós modellbe bekerült egy olyan változó, amelynek az esetében indokolt volt az egyik háttérváltozóval való kapcsolatot is megvizsgálni, ezt korrelációszámítással tettük meg, amelyet az eredmények fejezetben részleteztünk.

\section{Eredmények}

Az 1. ábra szemlélteti a Herzberg kérdésblokk eredményeit, melyek alapján megállapítható, hogy a „munkahelyi légkör” a „megbecsülés, tisztelet” és a „biztonság” tényezők mutatják a legmagasabb átlagértékeket.

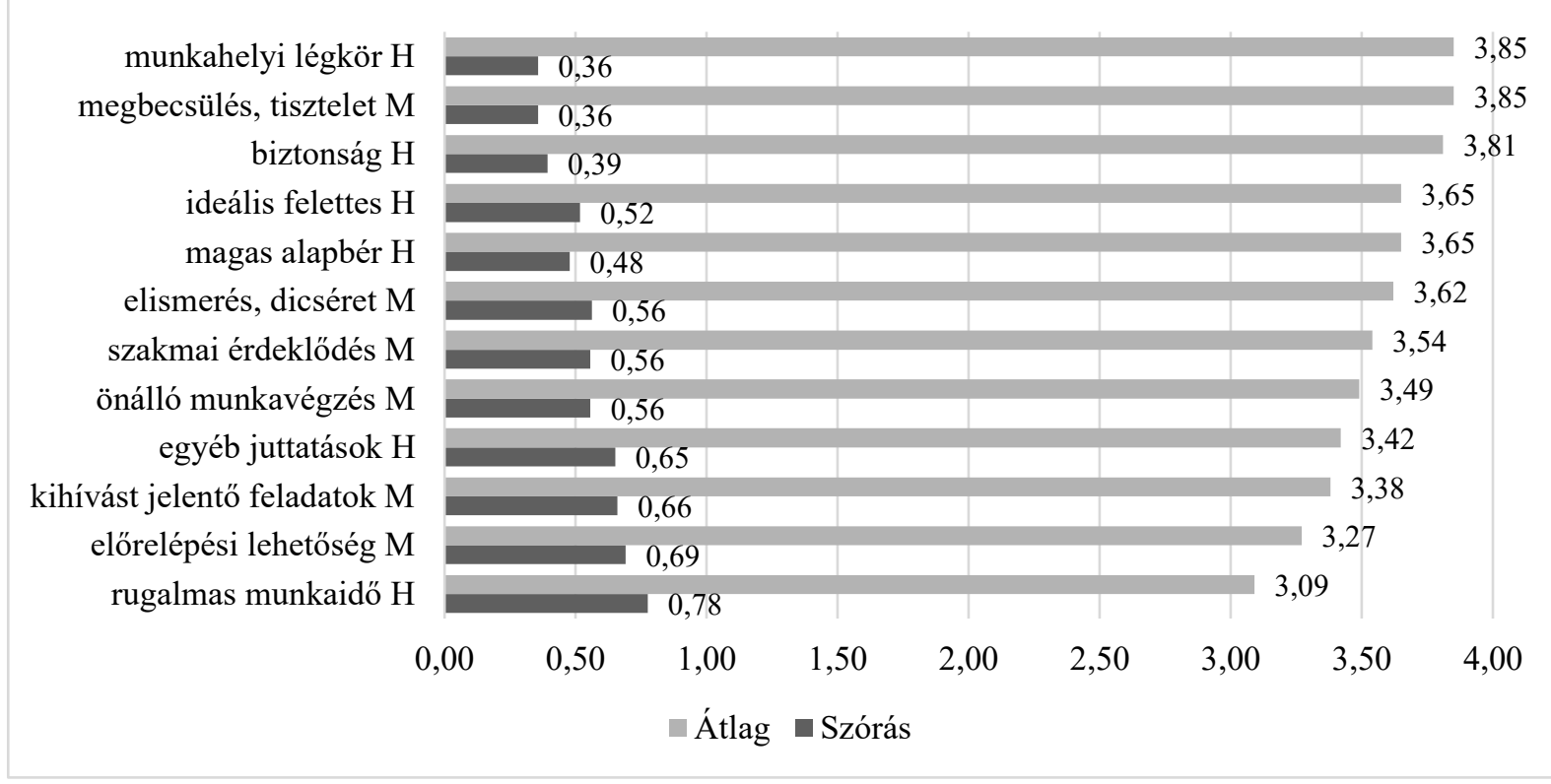

\section{1. ábra: Herzberg kérdésblokk átlagértékei}

Forrás: Saját vizsgálat

Az egyes itemek melletti „M” és „H” betükből látható a különbség, amely alapján a Herzberg modellben ezek közül az első helyen azonos átlag és szórás értékekkel végzett egy-egy higiénés tényezö $(\mathrm{H})$ és motivátor $(\mathrm{M})$. A munkahelyi légkör, bár higiénés tényező, vagyis alapvetően elvárt a munkavállalók részéről, az egyik legfontosabb napjainkban, ami egybeesik Csehné és Varga (2017) bevezetésben bemutatott kutatási eredményeivel. A magas átlagérték mögött az állhat a háttérben, hogy a szolgáltató szervezetnél a munkavállalók csapatban dolgoznak, közös 
munka eredményeképpen teremtenek értéket az ügyfelek számára, így különösen fontosnak érezhetik a döccenőmentes csapatmunkához szükséges munkahelyi légkör megteremtését. Az önálló munkavégzés $(\mathrm{M})$ viszonylag alacsony átlagértékei is a csapatmunka fontosságát erősítik.

A 2. ábra az Öndeterminációs kérdésblokk válaszainak átlag és szórás eredményeit szemlélteti. Megállapítható, hogy közel azonos szórás mellett a „kötődés”, a „kompetencia” és az „autonómia” sorrendjében jelennek meg az Öndeterminációs elmélet szükségletei. A három közül tehát a kollégákkal tartott kapcsolat (kötődés) kapta a legmagasabb átlagértéket, amely szintén az 1. ábrán, a munkahelyi légkörnél leírt csapatmunkára vezethető vissza. A munka jellegéből adódóan a dolgozók egymás outputjait használják inputként, a komplex, több ember munkáját igénylö folyamatok révén előálló értékteremtés intenzív együttmüködést igényel, ezáltal szoros kapcsolat alakulhat ki a kollégákkal.

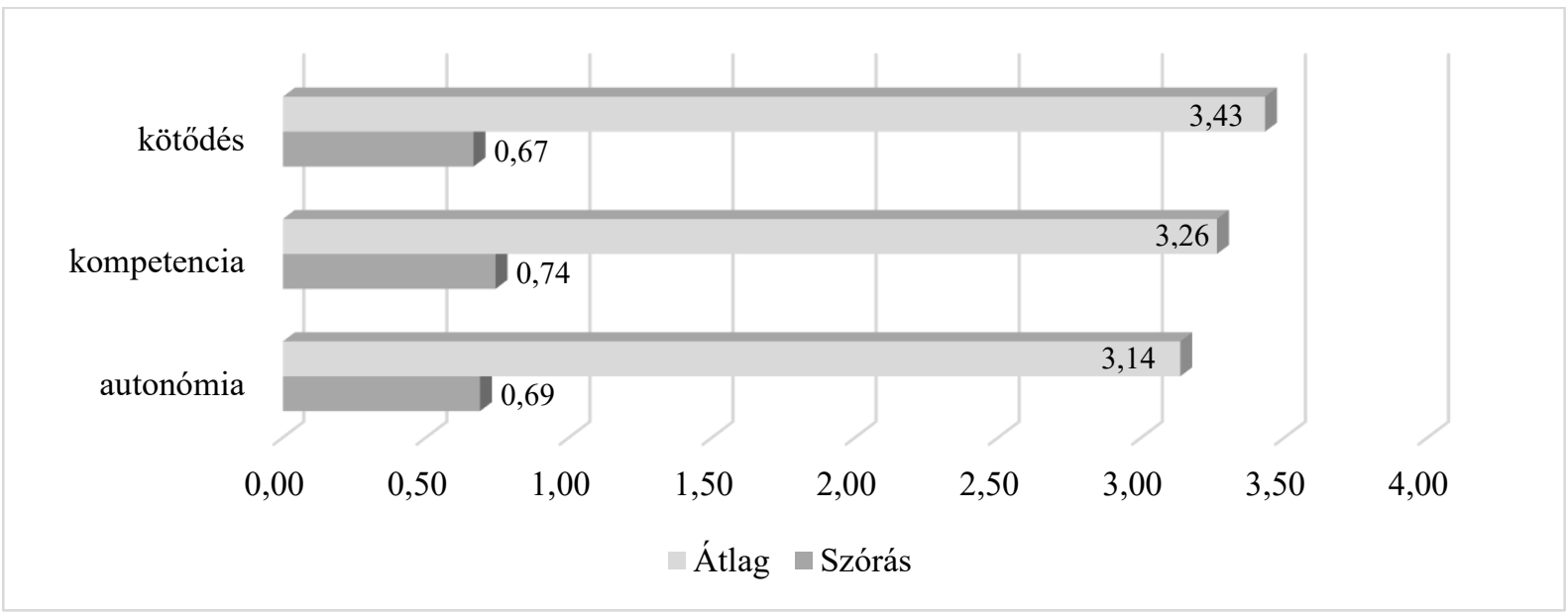

\section{2. ábra: Az Öndeterminációs kérdésblokk átlagértékei}

Forrás: Saját vizsgálat

A Regressziós modellbe beléptetett változók listáját tartalmazza a 3. táblázat. Stepwise módszernél, azaz lépésenkénti regressziónál a statisztikai program által mindig a legjobban korreláló változó hozzáadása történik meg. Az 1. és a 2. ábrán szereplő változók közül a 3. táblázatban szereplők kerültek beléptetésre.

\section{3. táblázat: Regressziós modellek hozzáadott változói}

\begin{tabular}{|c|c|c|}
\hline Modell & Hozzáadott új változó & Modellben szereplő változók \\
\hline 1 & $\begin{array}{l}\text { Kreatív, önálló munkavégzésre } \\
\text { való ösztönzés }\end{array}$ & $\begin{array}{l}\text { 1. Kreatív, önálló munkavégzésre való } \\
\text { ösztönzés }\end{array}$ \\
\hline 2 & $\begin{array}{l}\text { Egyéni szakmai fejlődés } \\
\text { biztosítása }\end{array}$ & $\begin{array}{l}\text { 1. Kreatív, önálló munkavégzésre való } \\
\text { ösztönzés } \\
\text { 2. Egyéni szakmai fejlődés biztosítása }\end{array}$ \\
\hline 3 & Alapbér fontossága & $\begin{array}{l}\text { 1. Kreatív, önálló munkavégzésre való } \\
\text { ösztönzés } \\
\text { 2. Egyéni szakmai fejlődés biztosítása } \\
\text { 3. Alapbér fontossága }\end{array}$ \\
\hline
\end{tabular}

Forrás: Saját vizsgálat 
A 3-as modell kapcsán megállapítható (4. táblázat), hogy az R2 és a korrigált R2 közötti eltérés 0,02 vagyis a modell stabilnak tekinthető. A modell a motivációs pontszámnak kb. 47,9\%-át tudta magyarázni. Ez a magyarázó erő 1\%-on szignifikáns volt.

\section{4. táblázat: Regressziós modell összefoglaló táblázata}

\begin{tabular}{|l|l|l|l|l|}
\hline \multicolumn{1}{|c|}{ Modell } & \multicolumn{1}{|c|}{$\mathbf{R}$} & \multicolumn{1}{c|}{$\mathbf{R}^{\mathbf{2}}$} & \multicolumn{1}{c|}{ Korrigált $\mathbf{R}^{\mathbf{2}}$} & \multicolumn{1}{c|}{ Standard hiba } \\
\hline 1 & 0,580 & 0,337 & 0,330 & 0,811 \\
\hline 2 & 0,679 & 0,461 & 0,450 & 0,735 \\
\hline $\mathbf{3}$ & $\mathbf{0 , 7 0 3}$ & $\mathbf{0 , 4 9 5}$ & $\mathbf{0 , 4 7 9}$ & $\mathbf{0 , 7 1 5}$ \\
\hline
\end{tabular}

Forrás: Saját vizsgálat

Az 5. táblázat már kizárólag a végső, 3-as modellre vonatkozó vizsgálat eredményeit ismerteti, amely már minden olyan változót magába foglal, amelyik beválogatható volt a modellbe. A „B” értékek alapján az első két változó pozitív kapcsolatban áll a motivációval, vagyis a „Kreatív, önálló munkavégzésre való ösztönzés” a többi változó változatlansága mellett 0,478 ponttal növeli a motiváció pontszámát, amely az „Egyéni szakmai fejlődés biztosítása” esetén 0,361 pontot jelent. Az „Alapbér fontossága” ezzel fordított irányú kapcsolatot mutat, minden más tényező változatlansága mellett ennek a független változónak a növekedése 0,185 ponttal csökkenti a motivációs pontszám értékét. Az 1. és a 2. ábránál írt csapatmunka esetében Dhurup et al. (2016) hangsúlyozza, hogy ha a dolgozók önállóan, egymástól függetlenül tevékenykednek, de a közös cél érdekében együttes felelősséget vállalnak, a szinergiahatásnak köszönhetően azzal is nagyobb teljesítményt érhetnek el annál, mintha teljesen egyénileg dolgoznának. Az eredmények alapján a csapatmunka és az önálló munkavégzés akkor növelheti a dolgozók motivációját, ha nincsenek szigorú keretek közé szorítva és lehetőségük van a kreatív munkavégzésre. A szakmai fejlődés biztosítása is erős motiváló erővel bír, amely az

1. ábrán szereplő „előrelépési lehetőség” alacsony átlagértékeiből adódóan nem feltétlenül kíván pozícióváltást, inkább az adott munkakörben való szaktudás elmélyítését hordozhatja magában.

5. táblázat: Végső modell változóinak $B$ és t értékei

\begin{tabular}{|l|l|l|}
\hline \multicolumn{1}{|c|}{ Változók } & \multicolumn{1}{c|}{ B } & \multicolumn{1}{c|}{ t } \\
\hline $\begin{array}{l}\text { Kreatív, önálló } \\
\text { munkavégzésre való } \\
\text { ösztönzés }\end{array}$ & 0,478 & $6,246^{*}$ \\
\hline $\begin{array}{l}\text { Egyéni szakmai fejlődés } \\
\text { biztosítása }\end{array}$ & 0,361 & $4,730^{*}$ \\
\hline Alapbér fontossága & $-0,185$ & $-2,542^{* *}$ \\
\hline
\end{tabular}

$\neg * 1 \%$-on szignifikáns, **5\%-on szignifikáns

Forrás: Saját vizsgálat

Annak tükrében, hogy az alapbér fontossága fordított irányú kapcsolatban áll a motivációval, indokolt volt az egyik bérhez kapcsolódó háttérváltozóval való viszonyt is megvizsgálni, ezt korrelációszámítással tettük meg. A 6. táblázatban látható eredmények alapján az alapbér fontossága és az elvégzett munka, kapott bérezés egyensúlya között fordított irányú a kapcsolat, vagyis az észlelésük alapján többet tesznek a szervezetért, mint amennyi ellenszolgáltatást kapnak érte, ami növeli az elégedetlenségüket. 


\section{6. táblázat: Magas alapbér fontossága és az elvégzett munka, kapott bérezés egyensúlya közötti kapcsolat}

\begin{tabular}{|l|l|l|}
\hline \multirow{2}{*}{} & \multicolumn{2}{|c|}{ Elvégzett munka, kapott bérezés egyensúlya } \\
\cline { 2 - 3 } & $\begin{array}{l}\text { Pearson korrelációs } \\
\text { együttható értéke }\end{array}$ & kétoldali szignifikancia $(\mathrm{p})$ \\
\hline Alapbér fontossága & $-0,301$ & 0,002 \\
\hline
\end{tabular}

Forrás: Saját szerkesztés

Az eredményekből levonható következtetéseket a következő fejezetben foglaltuk össze.

\section{Következtetések}

A vizsgálati eredmények alapján Herzberg modelljének tényezői közül a „munkahelyi légkör”, a „megbecsülés, tisztelet” és a „biztonság” kapták a legmagasabb átlagértékeket, mint legfontosabbnak tartott elvárások egy ideális munkahellyel szemben. Az Öndeterminációs elmélet rangsorában a kötődés, a kompetencia és az autonómia jelenti a sorrendet. A jó munkahelyi, társas kapcsolatoknak tehát mindkét vizsgált modell eredményei alapján kiemelkedően fontos szerepe van a dolgozók véleménye alapján, amelyet a bevezetésben részletezett más kutatási eredmények is alátámasztanak.

A mintából becsült regressziós modell szerint a „kreatív, önálló munkavégzésre való ösztönzés” (vagyis az autonómia) és ,az egyéni szakmai fejlődés biztosítása” (a kompetencia) növeli a dolgozók motiváltságát, viszont azoknak a munkavállalóknak, akiknek a magas alapbér egy ideális munkahellyel szemben kiemelten fontos elvárást jelent, a munkáltató által jelenleg biztosított munkabér csökkenti a motiváltságát. A bér csak bizonyos szintig csökkenti az elégedetlenséget, ezután nem lehet tovább csökkenteni. Mivel a bér befolyásoló tényezőként jelenik meg, ezért valószínűsíthető, hogy még nem érte el ezt a szintet a vizsgált mintánál, ez esetleg szervezeti, iparági sajátosságnak is tekinthető. A bér befolyásoló szerepének a jobb megértése érdekében megvizsgáltuk, hogy van-e összefüggés az alapbér fontossága és az elvégzett munka/megkapott munkabér között. Az eredmények alapján a dolgozók elégedetlenségét az okozza, hogy a dolgozók nem érzik arányosnak az elvégzett munkáért járó bérezést, vagyis a saját észlelésük alapján többet tesznek a szervezetért, mint amennyi ellenszolgáltatást kapnak érte, ami növeli az elégedetlenségüket. Ennek hátterét egy másik kutatás keretében érdemes lehet megvizsgálni, ugyanis az Anyag és módszer fejezetben részletezett méltányosság elmélet szerint valamely referencia személyekhez viszonyítják a saját input/eredmény arányukat a munkavállalók. Vajon szervezeten belüli személyekről lehet szó, vagy más, hasonló szervezet dolgozóiéhoz viszonyítva érzik méltánytalannak a jövedelmüket.

\section{Köszönetnyilvánítás}

A publikáció EFOP3.6.3-VEKOP-16-2017-00007-"Tehetségből fiatal kutató" - A kutatói életpályát támogató tevékenységek a felsőoktatásban projekt támogatásával készült.

\section{Irodalomjegyzék}

1. Avolio, B. J. - Bass, B. M. (1991): The full range of leadership development: Basic and advanced manuals. NY: Bass,. Binghamton.

2. Bakacsi Gy. (2004): Szervezeti magatartás és vezetés. Budapest: AULA Kiadó.

3. Bakacsi Gy. (2015): A szervezeti magatartás alapjai. Alaptankönyv bachelor hallgatók számára. Semmelweis Kiadó, Budapest, 2015. ISBN 978-963-331-313-8. 
4. Csehné P. I. - Varga E. (2017): 'A munka-magánélet egyensúly a magyar vállalatok gyakorlatában', Studia Mundi - Economica, 4(1), pp. 15-25.

5. Deci, E. L. - Ryan, R. M. (2012): 'Self-determination theory', In P. A. M. Van Lange, A. W. Kruglanski, \& E. T. Higgins (Eds.), Handbook of theories of social psychology, pp. 416-436.

6. Deci, E. L. - Ryan, R. M. (2017): Self-Determination Theory: Basic Psychological Needs in Motivation, Development, and Wellness.

7. Dhamija, P., Gupta, S., Bag, S. (2019): 'Measuring of job satisfaction: the use of quality of work life factors', Benchmarking, 26(3), pp. 871-892. doi: 10.1108/BIJ-062018-0155.

8. Dhurup, M., Surujlal, J., Kabongo, D. M. (2016): 'Finding Synergic Relationships in Teamwork, Organizational Commitment and Job Satisfaction: A Case Study of a Construction Organization in a Developing Country', Procedia Economics and Finance. Elsevier B.V., 35(October 2015), pp. 485-492. doi: 10.1016/s22125671(16)00060-5.

9. Dvir, T. Eden, D., Avolio, BJ., Shamir B. (2002): 'Impact of Transformational Leadership on Follower Development and Performance: A Field Experiment', Academy of Management Journal. Academy of Management, 45(4), pp. 735-744. doi: 10.5465/3069307.

10. Erro-Garcés, A. - Ferreira, S. (2019): 'Do better workplace environmental conditions improve job satisfaction?', Journal of Cleaner Production, 219, pp. 936-948. doi: 10.1016/j.jclepro.2019.02.138.

11. Farkas F., Jarjabka Á., Lóránd B., Bálint B. (2013): 'Munkahelyi motivációk Magyarországon 2013-ban', Vezetéstudomány / Budapest Management Review, XLIV.(10.), pp. 12-23.

12. Fenyves V., Bács Z., Karnai L., Nagy A., Tarnóczi T. (2018): 'Financial performance measurement of hungarian retail food companies', Contemporary Economics, 12(4 Special Issue), pp. 459-472. doi: 10.5709/ce.1897-9254.290.

13. Gergely É. - Pierog A. (2016): 'Motivációs tényezők feltárása civil és profitorientált szervezeteknél', Gradus, 3(1), pp. 368-373.

14. Herzberg, F. (1987): 'One more time: How do you motivate employees?', Harvard Business Review, 65(5), pp. 109-120.

15. Hur, Y. (2018): 'Testing Herzberg's Two-Factor Theory of Motivation in the Public Sector: Is it Applicable to Public Managers?', Public Organization Review. Public Organization Review, 18(3), pp. 329-343. doi: 10.1007/s11115-017-0379-1.

16. Juhász Cs. (2004): 'Motivációs lehetőségek vizsgálata az élelmiszer-gazdaságban'. Debreceni Egyetem, Interdiszciplináris Társadalom- és Agrártudományok Doktori Iskola, doktori értekezés, pp.13-24.

17. Kanat-Maymon, Y., Elimelech, M., Roth, G. (2020): 'Work motivations as antecedents and outcomes of leadership: Integrating self-determination theory and the full range leadership theory', European Management Journal. Elsevier Ltd, (megjelenés alatt). doi: 10.1016/j.emj.2020.01.003.

18. Kiss Á. G. (2015): 'Tanulási motivációk vizsgálata a Szent István Egyetem hallgatóinak körében', Studia Mundi - Economica, 1(2), pp. 127-137.

19. Kiss Zs. - Barizsné H. E. (2018): 'Álláskeresés diplomával', Taylor: Gazdálkodás- és Szervezéstudományi Folyóirat: A Virtuális Intézet Közép-Európa Kutatására Közleményei, 10(1), pp. 84-90.

20. Kiss Zs., Barizsné H. E., Kun A. (2017): 'A leendő munkavállalás hallgatói szemmel : Egy a debreceni egyetem alapszakos hallgatói körében végzett felmérés eredményei', 
Taylor: Gazdálkodás- és Szervezéstudományi Folyóirat: A Virtuális Intézet KözépEurópa Kutatására Közleményei, 9(1), pp. 183-190.

21. Kreitner, R. - Kinicki, A. (2009): Organizational Behavior Ninth Edition. New York: McGraw-Hill/Irwin.

22. Nalipay, M. J. N., King, R. B. - Cai, Y. (2020): 'Autonomy is equally important across East and West: Testing the cross-cultural universality of self-determination theory', Journal of Adolescence. Elsevier, 78(June 2019), pp. 67-72. doi: 10.1016/j.adolescence.2019.12.009.

23. Sipos N. (2016): 'A munkaelégedettség Herzberg-modelljének továbbfejlesztése a Frissdiplomások 2011-2014 adatbázisok alapján', Vezetéstudomány / Budapest Management Review, XLVII.(12), pp. 97-108. doi: 10.14267/veztud.2016.12.09.

24. Sunil, R. (2004): 'A Review of Employee Motivation Theories and their Implications for Employee Retention within Organizations', The Journal of American Academy of Business, pp. 52-63.

25. Varga E., Szira Z., Boda H., Hajós L. (2017): ‘A munkaerőpiacon elvárt kompetenciák relevanciájának összehasonlító elemzése a munkáltatók és a felsőoktatásban végzős fiatal munkavállalók aspektusából', Studia Mundi - Economica, 4(1), pp. 82-93. 